\title{
Measurement of Redox States of the $\beta 3$ Integrin Disulfide Bonds by Mass Spectrometry
}

Joyce Chiu*

Centenary Institute, NHMRC Clinical Trials Centre, Sydney Medical School, the University of Sydney NSW 2006, Sydney, Australia

*For correspondence: joyce.chiu@sydney.edu.au

\begin{abstract}
[Abstract] Functional disulfide bonds mediate a change in protein function in which they reside when cleaved or formed. To elucidate how a functional disulfide bond controls protein activity, it is critical that the redox state of the bond in the population of protein molecules is known. Measurement of changes in disulfide bond redox state relies on thiol probes and immunoblotting. Such technique only offers a qualitative indication of a change in redox state but not the identity of cysteines involved. A differential cysteine alkylation and mass spectrometry technique is described here that affords precise quantification of protein disulfide bond redox state. The utility of the technique is demonstrated by quantifying the redox state of 24 of the 28 disulfide bonds in human $\beta 3$ integrin from purified platelets.
\end{abstract}

Keywords: Disulfide bonds, Redox, Alkylation, Proteomics, Integrin

[Background] Disulfide bonds are covalent linkages between two cysteine residues in a protein. There are three types of disulfide bonds found in proteins: structural, catalytic and functional. Structural disulfide bonds stabilize protein conformation and are the most common type disulfide bonds. Catalytic disulfide bonds are found in redox enzymes such as thioredoxin and protein disulfide isomerases that reduce and oxidize disulfide bonds in substrate proteins. Functional disulfide bonds mediate a change of protein function such as activity, ligand affinity, localization or multimerization when cleaved or formed. Our understanding of how functional disulfides control protein function is limited by the molecular techniques available to detect changes in cysteines and disulfide bonds. Measurement of changes in disulfide redox state has mainly relied on the use of thiol probes such as biotin-conjugated maleimide (3-(N-maleimidylpropionyl)biocytin), followed by detection using streptavidin conjugated-peroxidase (Manickam et al., 2008). This provides a qualitative indication of a change in redox state and does not identify which cysteines are involved. The development of isotopic cysteine alkylators (unlabeled and ${ }^{13}$ Carbon labeled) has allowed differential cysteine alkylation, and mass spectrometry allows for an estimation of the fraction of a protein disulfide bond that is reduced in the protein preparation (Chambers et al., 2010).

In the method described herein, reduced disulfide bond cysteines are alkylated with 2-iodo-Nphenylacetamide $\left({ }^{12} \mathrm{C}\right.$-IPA $)$ and the oxidized disulfide bond cysteines with a stable carbon-13 isotope of IPA $\left({ }^{13} \mathrm{C}\right.$-IPA $)$ following reduction with dithiothreitol. The ratio of alkylation of peptides containing the disulfide bond cysteines with ${ }^{12} \mathrm{C}$-IPA compared to ${ }^{13} \mathrm{C}$-IPA represents the fraction of the disulfide in the population that is in the reduced state. The advantage of this pair of cysteine alkylators is that they have the same chemical reactivity and the same structure, which enhances the reliability of alkylation, 
resolution of the alkylated peptides by liquid chromatography and their detection by mass spectrometry (Pasquarello et al., 2004). A mass difference of $6 \mathrm{Da}$ is the only change in a cysteine labeled with ${ }^{12} \mathrm{C}$ IPA or ${ }^{13} \mathrm{C}-I P A$.

To exemplify this technique, the redox state of disulfide bonds in $\beta 3$ integrin from platelet is calculated. Based on the published crystal structure (PDB: 3FCS), there are 56 cysteines that form 28 disulfide bonds in $\beta 3$ integrin. Using this protocol, sixty-eight IPA-labeled peptides encompassing 34 of the 56 cysteines in the $\beta 3$ integrin subunit were resolved, which represents 24 of the $28 \beta 3$ integrin disulfide bonds. Among the 24 disulfide bonds measured, one disulfide bond, Cys177-184, is subjected to cleavage by disulfide-cleaving enzyme ERp5, thereby regulating ligand affinity of $\beta 3$ integrin on platelet surface (Passam et al., 2018).

\section{Materials and Reagents}

1. Ziptip ${ }^{\circledR}$ C18 pipette tip (Millipore, catalog number: ZTC18S96)

2. $1.5 \mathrm{ml}$ tubes

3. Natural human allb $\beta 3$ protein purified from human platelets (Abcam, catalog number: ab95130)

4. Anti-integrin $\beta 3$ (GPIIla, CD61) PSI domain [AP-3] antibody (Kerafast, catalog number: EBW106)

5. 2-iodo-N-phenylacetamide ( ${ }^{12} \mathrm{C}$-IPA) (Cambridge isotopes, catalog number: ULM-8131-PK)

6. ${ }^{13} \mathrm{C}$-2-iodo-N-phenylacetamide $\left({ }^{13} \mathrm{C}\right.$-IPA) (Cambridge isotopes, catalog number: CLM-8130-0.1)

7. Dimethyl sulfoxide (DMSO) (Sigma, catalog number: D8418)

8. NuPAGE ${ }^{\mathrm{TM}} 4 x$ LDS sample loading buffer (Thermo Fisher Scientific, catalog number: NP0007)

9. NuPAGE ${ }^{\mathrm{TM}} 4-12 \%$ Bis-Tris gel $1.5 \mathrm{~mm}$, 10-well (Thermo Fisher Scientific, catalog number: NP0335BOX)

10. NUPAGE ${ }^{T M}$ MOPS running buffer 20x (Thermo Fisher Scientific, catalog number: NP0001)

11. Brilliant Blue $G$ solution (Sigma, catalog number: B8522-1EA)

12. Ammonium bicarbonate (Sigma, catalog number: A6141)

13. Dithiothreitol (DTT) (Sigma, catalog number: D0632)

14. Formic acid LC-MS grade (Thermo Fisher Scientific, catalog number: 28905)

15. Trifluoroacetic acid (Sigma, catalog number: 302031)

16. Formic acid (Sigma, catalog number: F0507)

17. Acetonitrile HPLC grade (Fisher Chemical, catalog number: 10407440)

18. PNGase F Proteomics grade enzyme (Sigma, catalog number: P7367)

19. Sequencing grade bovine chymotrypsin (Roche, catalog number: 11418467001)

20. Trypsin Gold, Mass spectrometry grade (Promega, catalog number: V5280)

21. $\mathrm{HCl}$

22. Acetic acid

23. Calcium chloride

24. Methanol 
25. Coomassie blue

26. $\mathrm{NaCl}$

27. $\mathrm{KCl}$

28. $\mathrm{Na}_{2} \mathrm{HPO}_{4}$

29. $\mathrm{KH}_{2} \mathrm{PO}_{4}$

30. PBS (see Recipes)

31. Gel destaining solution (see Recipes)

32. $50 \mathrm{mM}{ }^{12} \mathrm{C}$-IPA/DMSO solution (see Recipes)

33. $50 \mathrm{mM}{ }^{13} \mathrm{C}$-IPA/DMSO solution (see Recipes)

34. $5 \mathrm{mM}{ }^{13} \mathrm{C}-\mathrm{IPA} / 25 \mathrm{mM}$ ammonium bicarbonate (see Recipes)

35. $25 \mathrm{mM}$ ammonium bicarbonate buffer (see Recipes)

36. $25 \mathrm{mM}$ ammonium bicarbondate $/ 50 \%$ acetonitrile buffer (see Recipes)

37. $25 \mathrm{mM}$ ammonium bicarbonate/10 $\mathrm{mM}$ calcium chloride buffer (see Recipes)

38. $1 \mathrm{M}$ calcium chloride solution (see Recipes)

39. $40 \mathrm{mM} \mathrm{DTT} / 25 \mathrm{mM}$ ammonium bicarbonate (see Recipes)

40. $1 \mathrm{mM} \mathrm{HCl}$ solution (see Recipes)

41. $50 \mathrm{mM}$ acetic acid (see Recipes)

42. $5 \%$ formic acid (see Recipes)

43. $5 \%$ formic acid $/ 50 \%$ acetonitrile buffer (see Recipes)

44. $1 \%$ trifluoroacetic acid solution (see Recipes)

45. Wetting solution (see Recipes)

46. Equilibration solution (see Recipes)

47. $0.1 \%$ formic acid (see Recipes)

48. HPLC Buffer A (see Recipes)

49. HPLC Buffer B (see Recipes)

\section{Equipment}

1. Pipettes

2. Scalpel

3. Centrifuge

4. Speedivac SC210P1-15 (Thermo Fisher Scientific)

5. Thermomixer $\mathrm{R}$ with $1.5 \mathrm{ml}$ block (Eppendorf, catalog number: Z605271)

6. Q-Exactive Plus Dionex Ultimate 3000 (Thermo Fisher Scientific) or an equivalent Orbitrap mass spectrometer such as Velos (Thermo Fisher Scientific) or Q-Exactive Classic (Thermo Fisher Scientific)

7. $-20^{\circ} \mathrm{C}$ freezer

8. $-80{ }^{\circ} \mathrm{C}$ freezer

9. NanoDrop 


\section{Software}

1. RawConverter (free download at http://fields.scripps.edu/rawconv/) (He et al., 2015)

2. Mascot search database (Matrix Science)

3. Peptide/Protein MS Product Utility Program MS-Product from Protein Prospector Tools (http://prospector.ucsf.edu/prospector/cgi-bin/msform.cgi?form=msproduct)

4. Qual Browser from XCalibur Software 2.2 (Thermo Fisher Scientific)

5. Microsoft Excel (Microsoft) or equivalent spreadsheet tool

\section{Procedure}

A. Differential cysteine labeling and in-gel digestion

Note: All washes that require mixing and incubations of samples are performed using Thermomixer $R$ with a block that holds $1.5 \mathrm{ml}$ tubes.

1. To $6 \mu \mathrm{g}$ of natural human allbß3, add PBS to $25 \mu \mathrm{l}$.

Note: For lyophilized proteins, a non-amide buffer with $\mathrm{pH}>7.0$ (e.g., PBS) is recommended for reconstitution.

2. Add $2.2 \mu \mathrm{l}$ of $50 \mathrm{mM}{ }^{12} \mathrm{C}$-IPA/DMSO solution to final $4 \mathrm{mM}$. Mix and incubate at $25^{\circ} \mathrm{C}$ for $1 \mathrm{~h}$ in the dark.

Note: Prepare fresh ${ }^{12} \mathrm{C}$-IPA/DMSO solution just before use. Discard any unused solution. Cysteine is a strong nucleophile, and its reaction with IPA should complete in $1 \mathrm{~h}$. Extended incubation time with IPA is not recommended.

3. Add $9 \mu \mathrm{l}$ of NuPAGE ${ }^{\mathrm{TM}} 4 \mathrm{x}$ LDS sample loading buffer and heat samples at $70{ }^{\circ} \mathrm{C}$ for $10 \mathrm{~min}$.

4. Analyze samples on non-reducing NuPAGE ${ }^{\mathrm{TM}} 4-12 \%$ Bis-Tris gel in $1 \times$ MOPS running buffer at $150 \mathrm{~V}$ for $65 \mathrm{~min}$.

5. Stain protein gel with $40 \mathrm{ml}$ of Coomassie Blue $\mathrm{G}$ solution at room temperature for $30 \mathrm{~min}$. Remove Coomassie Blue $\mathrm{G}$ solution.

6. Destain gel in destaining solution at room temperature until background becomes clear.

7. Excise protein gel bands corresponding to $\beta 3$ integrin (Figure 1) with a clean scalpel.

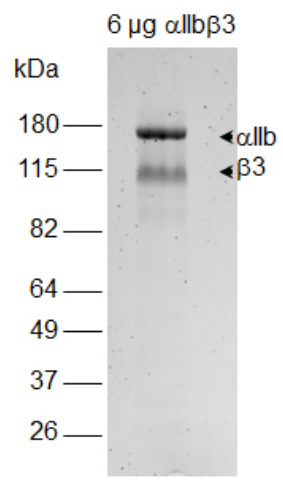

Figure 1. Analysis of allb $\beta 3$ integrin by non-reducing SDS-PAGE. Bands corresponding to 
$\beta 3$ are excised for subsequent in-gel processing of samples. A photo of Coomassie blue stained gel is shown.

8. Dice gel band into small pieces of 1-2 $\mathrm{mm}^{3}$. Place gel pieces into a clean tube.

Note: Use standard 1.5 tubes that are nuclease-free. Special low protein binding tubes are not required.

9. Add $150 \mu \mathrm{l}$ of $25 \mathrm{mM}$ ammonium bicarbonate $/ 50 \%$ acetonitrile buffer to gel pieces.

10. Vortex gel pieces for $10 \mathrm{~min}$ at $25^{\circ} \mathrm{C}$ using Thermomixer (Eppendorf). Remove supernatant by pipetting.

11. Repeat Steps $A 9$ and $A 10$ for another 2 washes of the gel pieces.

12. Dry gel pieces by adding $100 \mu$ of $100 \%$ acetonitrile. Remove acetonitrile by pipetting. Note: Gel pieces should be completely dried out within 1-2 min. Can store dried gel slices after this step at $-20^{\circ} \mathrm{C}$. Long-term storage of dried gel slices is not recommended. However, the dried gel slices stored under this condition should remain stable for 1 month or longer.

13. Cover gel pieces with $80 \mu \mathrm{l}$ of $40 \mathrm{mM}$ DTT in $25 \mathrm{mM}$ ammonium bicarbonate buffer. Incubate at $56{ }^{\circ} \mathrm{C}$ for $30 \mathrm{~min}$. Remove supernatant.

14. Wash three times with $150 \mu \mathrm{l}$ of $25 \mathrm{mM}$ ammonium bicarbonate/50\% acetonitrile buffer. Vortex each time for $10 \mathrm{~min}$ at $25^{\circ} \mathrm{C}$.

15. Dry gel slices by adding $100 \mu \mathrm{l}$ of $100 \%$ acetonitrile. Remove acetonitrile by pipetting. Note: It is not recommended to store gel pieces with proteins that contain free thiols generated from DTT reduction prior to alkylation with ${ }^{13} \mathrm{C}$-IPA. Gel pieces can be stored at $-20{ }^{\circ} \mathrm{C}$ after alkylation with ${ }^{13} \mathrm{C}$-IPA, washed and dehydrated with $100 \%$ acetonitrile.

16. Prepare $50 \mathrm{mM}{ }^{13} \mathrm{C}$-IPA/DMSO solution and dilute it to $5 \mathrm{mM}{ }^{13} \mathrm{C}-\mathrm{IPA}$ in $25 \mathrm{mM}$ ammonium bicarbonate buffer.

Note: Prepare fresh ${ }^{13} \mathrm{C}-I P A / D M S O$ solution and dilute it to $5 \mathrm{mM}{ }^{13} \mathrm{C}-I P A / 25 \mathrm{mM}$ ammonium bicarbonate solution just before use. $5 \mathrm{mM}{ }^{13} \mathrm{C}$-IPA/25 mM ammonium bicarbonate solution can precipitate slightly. Discard any unused solution.

17. Cover gel pieces with $100 \mu \mathrm{l}$ of $5 \mathrm{mM}{ }^{13} \mathrm{C}-\mathrm{IPA} / 25 \mathrm{mM}$ ammonium bicarbonate solution and incubate in the dark for $1 \mathrm{~h}$ at $25^{\circ} \mathrm{C}$. Remove supernatant.

18. Wash three times with $150 \mu \mathrm{l}$ of $25 \mathrm{mM}$ ammonium bicarbonate/50\% acetonitrile buffer. Vortex each time for $10 \mathrm{~min}$ at $25^{\circ} \mathrm{C}$.

19. Dry gel slices by adding $100 \mu \mathrm{l}$ of $100 \%$ acetonitrile. Remove acetonitrile by pipetting.

20. Dry gel pieces in Speedivac for 15-20 min to remove traces of acetonitrile prior to enzymatic processing of gel pieces.

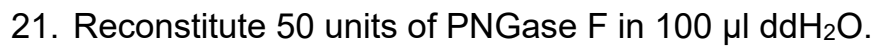

Note: Any unused PNGase $F$ can be stored at $-20^{\circ} \mathrm{C}$. The enzyme remains stable for a few freeze-thawing cycles. For non-glycosylated proteins, skip PNGase F treatment (Steps A22A28) and directly go to Step A29 to digest protein. 
22. Add $10 \mu \mathrm{l}$ (5 units) of the reconstituted PNGase $\mathrm{F}$ to dried gel pieces and incubate at $37^{\circ} \mathrm{C}$ for 15-30 min.

Note: It is a very small volume to add to dried gel pieces, but it is not recommended to increase the volume of PNGase F by either diluting the enzyme or using more of the enzyme. Increased amount of PNGase $F$ used can result in more PNGase F peptides that can distract the mass spectrometer in data acquisition.

23. Add $25 \mu \mathrm{l}$ of water to the sample such that the gel pieces are just covered by the liquid.

24. Incubate at $37^{\circ} \mathrm{C}$ overnight.

25. Centrifuge briefly to collect condensation. Remove and discard supernatant from the samples.

26. Wash gel pieces with $250 \mu \mathrm{l}$ of water and vortex at $25^{\circ} \mathrm{C}$ for $20 \mathrm{~min}$. Remove supernatant.

27. Repeat Step A26 twice for 2 more washes.

28. Dry gel pieces in Speedivac until gel pieces are completely dried. Note: It may take up to $1 \mathrm{~h}$ to dry the gel pieces because of high water content.

29. Reconstitute chymotrypsin with $1 \mathrm{mM} \mathrm{HCl}$ to a final concentration of $1 \mathrm{mg} / \mathrm{ml}$. Note: Reconstituted chymotrypsin can be stored at $4{ }^{\circ} \mathrm{C}$ for 1 month.

30. Dilute chymotrypsin to $12.5 \mathrm{ng} / \mu \mathrm{l}$ in $25 \mathrm{mM}$ ammonium bicarbonate/10 mM CaCl 2 buffer.

31. Add $35 \mu \mathrm{l}$ of freshly diluted chymotrypsin to dried gel pieces and incubate at $37^{\circ} \mathrm{C}$ for $4 \mathrm{~h}$.

32. Reconstitute trypsin with $50 \mathrm{mM}$ acetic acid to a final concentration of $1 \mathrm{mg} / \mathrm{ml}$. Note: Reconstituted trypsin can be stored in $5 \mu$ laliquots at $-80^{\circ} \mathrm{C}$ for over a year.

33. Dilute trypsin to $12.5 \mathrm{ng} / \mu \mathrm{l}$ in $25 \mathrm{mM}$ ammonium bicarbonate buffer.

34. Add $30 \mu \mathrm{l}$ of freshly diluted trypsin to gel pieces and incubate at $25^{\circ} \mathrm{C}$ overnight.

35. Stop digestion of protein by adding $10 \mu \mathrm{l}$ of $5 \%$ formic acid solution to sample.

36. Transfer digest solution which contains peptides to a fresh tube.

37. Elute remaining peptides from gel slices by adding $30 \mu \mathrm{l}$ of $5 \%$ formic acid $/ 50 \%$ acetonitrile solution to gel slices. Vortex for $20 \mathrm{~min}$ at $25^{\circ} \mathrm{C}$.

38. Transfer supernatant to the tube containing peptides.

39. Repeat Step A37 for another elution of peptides from gel pieces.

40. Dry peptides with Speedivac with no heat applied.

B. Peptide clean up and mass spectrometry analysis

1. Reconstitute peptides in $10 \mu \mathrm{l}$ of $1 \%$ trifluoroacetic acid.

2. Using a P10 pipet, wet the C18 Ziptip by aspirating $10 \mu \mathrm{l}$ of wetting solution. Discard solution to waste.

Note: Avoid introducing air to the C18 matrix when pipetting.

3. Repeat Step B2 for a second time.

4. Equilibrate Ziptip using $10 \mu \mathrm{l}$ of Equilibration buffer. Discard solution to waste.

5. Repeat Step B4 for another two times.

6. Bind peptides by aspirating $10 \mu \mathrm{l}$ of the reconstituted peptide sample. Aspirate up and down no more than 4 times. 
Note: Do not aspirate more than 4 times as this will select for high-affinity peptides and lose peptides that only weakly bind to C18 matrix.

7. Wash column by aspirating $10 \mu \mathrm{l}$ of Equilibration buffer. Discard wash to waste.

8. Repeat Step B7 for another 2 times.

9. Elute bound peptides using $5 \mu$ l of wetting solution by aspirating up and down 3 times in a clean tube.

10. Dry peptides in Speedivac with no heat applied.

11. Reconstitute peptides in $12 \mu \mathrm{l}$ of $0.1 \%$ formic acid.

12. Measure the concentration of peptide using a NanoDrop. Use $0.1 \%$ formic acid as blank.

13. Dilute the peptide to $80 \mathrm{ng} / \mu \mathrm{l}$ with $0.1 \%$ formic acid.

14. Inject $3 \mu$ l of peptides (200-250 ng) into a Thermo Scientific Dionex Ultimate 3000 and analyze peptides on a $35 \mathrm{~cm} \times 75 \mu \mathrm{m}$ C18 reverse phase analytical column with integrated emitter using a gradient of $2 \%-35 \%$ acetonitrile over $22 \mathrm{~min}$ (Table 1) with a flow rate of $300 \mathrm{nl} / \mathrm{min}$.

Note: Mass spectrometry analysis is best to be performed at a proteomic facility where technical support can be provided to set up the method to run peptide samples. The intensity of the TIC peaks should be in the range of 1E9-1E10.

Table 1. Solvent gradient used in LC

\begin{tabular}{|l|l|l|}
\hline Time (min) & \% Buffer A & \% Buffer B \\
\hline 0 & 97 & 2 \\
\hline 20 & 97 & 2 \\
\hline 22 & 90 & 10 \\
\hline 44 & 60 & 40 \\
\hline 47 & 5 & 95 \\
\hline 50 & 5 & 95 \\
\hline 50.1 & 95 & 2 \\
\hline 60 & 95 & 2 \\
\hline
\end{tabular}

Acetonitrile gradient for peptide elution is highlighted.

15. Tandem mass spectrometry (MS/MS) analysis is performed on a Q-Exactive Plus mass spectrometer (Thermo Scientific) using HCD fragmentation. Set electrospray ionization of peptides at $+2.0 \mathrm{kV}$. The scan range for full MS is set at 350 to $1,750 \mathrm{~m} / \mathrm{z}$. The spectrum data type for full MS is profile mode whereas for MS/MS is centroid mode.

16. Data-dependent acquisition method is used to obtain MS/MS spectra of the top 10 most abundant ions at any one point during the gradient. 


\section{Data analysis}

A. Identification of peptides using Mascot search engine

1. Data files generated from LC-MS/MS (.raw) are converted to mascot generic format (.mgf) using RawConverter (He et al., 2015).

2. Using Mascot Daemon, set parameters under Parameter Editor.

a. Taxonomy: All entries.

b. Database: Swissprot.

c. Variable modification: click select modification and show all modifications. Select iodoacetanilide derivative $(\mathrm{C})$, iodoacetanilide ${ }^{13} \mathrm{C}$ derivative $(\mathrm{C})$, oxidation $(\mathrm{M})$ and deamidation (NQ).

d. Variable modifications, select all modifications, then choose iodoacetanilide derivative (C), iodoacetanilide ${ }^{13} \mathrm{C}$ derivative $(C)$, oxidation (M) and deamidation (NQ).

e. Select enzymes as TrypChymo.

f. Select Max. Missed cleavages to 3 .

g. Select monoisotopic for mass.

h. Select peptide charge $2+, 3+$ and $4+$.

i. Set peptide tolerance at $\pm 6 \mathrm{ppm}$ and $\mathrm{MS} / \mathrm{MS}$ tolerance at $\pm 0.6 \mathrm{Da}$.

j. Select MS/MS ions search.

k. Data format as Mascot generic.

I. Save parameter settings as beta3_integrin.par.

3. Under Task Editor, add .mgf files to be analyzed by mascot search and set parameter by choosing beta3_integrin.par file. Then start the search by pressing the Run button.

4. Once the search is completed, click the hyperlink for Results file URL to bring up the search data. To obtain sufficient cysteine-containing peptides for quantification of the redox state of disulfide bonds, it will require $65 \%-80 \%$ coverage of $\beta 3$ integrin.

5. Identify all cysteine-containing peptides from mascot search and tabulate them in a spreadsheet in Microsoft Excel.

B. Calculating $\mathrm{m} / \mathrm{z}$ ratios of cysteine-containing peptides

1. Using the list of cysteine-containing peptides identified by Mascot, calculate their monoisotopic mass/charge ratio $(\mathrm{m} / \mathrm{z})$ of $+2,+3$ and +4 using Peptide/Protein MS Product Utility Program MSProduct.

2. Cys-iodoacetanilide has a mass adduct of 133.05276 , and $\mathrm{Cys}-{ }^{13} \mathrm{C}$-iodoacetanilide has a mass adduct of 139.07289 , which are differed by 6 Da due to the six ${ }^{13} \mathrm{C}$-carbon ring on IPA (Table 2).

a. To calculate the $\mathrm{m} / \mathrm{z}$ ratios of the peptide, for example, ISPPEALENPCY from $\beta 3$, enter ISPPEALENPC (133.05276)Y and ISPPEALENPC(139.07289) $Y$ as input sequences in MSProduct from Protein Prospector for ${ }^{12} \mathrm{C}$-IPA and ${ }^{13}$-IPA labeled peptides, respectively. 
b. Set charge to 4 to obtain values of $\mathrm{m} / \mathrm{z}$ ratios from +1 to +4 . Values for $\mathrm{m} / \mathrm{z}$ ratios should be at least 4 decimal places (Table 3 ).

c. Tabulate the $\mathrm{m} / \mathrm{z}$ ratios $(+2,+3$ and +4$)$ in the same spreadsheet that recorded all cysteinecontaining peptides identified.

Table 2. Monoisotopic mass of adduct in cysteine

\begin{tabular}{|l|l|l|l|}
\hline Amino acid & Modification & Monoisotopic Mass $^{*}$ & Composition $^{*}$ \\
\hline Cys & lodoacetanilide & 133.052764 & $\mathrm{H}(7) \mathrm{C}(8) \mathrm{N} \mathrm{O}$ \\
\hline Cys & ${ }^{13} \mathrm{C}$-lodoacetanilide & 139.072893 & $\mathrm{H}(7) \mathrm{C}(2){ }^{13} \mathrm{C}(6) \mathrm{N} \mathrm{O}$ \\
\hline
\end{tabular}

*Values and composition are obtained from Unimod (www.unimod.org/).

Table 3. Monoisotopic $\mathrm{m} / \mathrm{z}$ ratios for ISPPEALENPCY peptide from $\beta 3$ integrin

\begin{tabular}{|l|l|l|l|l|}
\hline Cys-label & Sequence & $\mathbf{m} / \mathbf{z}$ \\
\cline { 3 - 5 } & & $\mathbf{+ 2}$ & $\mathbf{+ 3}$ & $\mathbf{+ 4}$ \\
\hline${ }^{12} \mathrm{C}-$ IPA & ISPPEALENPC(133.05276)Y & 733.3370 & 489.2271 & 367.1722 \\
\hline${ }^{13} \mathrm{C}-$ IPA & ISPPEALENPC(139.07289)Y & 736.3471 & 491.2338 & 368.6772 \\
\hline
\end{tabular}

C. Quantification of the abundance of single cysteine-containing peptide using XCalibur Qual Browser

1. To calculate ion abundance of peptides, extracted ion chromatograms were generated using the XCalibur Qual Browser software. Set autoprocessing parameters and display options for chromatogram and spectra as follows:

a. Activate the chromatogram cell (top panel) by selecting the pin 9 at the upper right corner. To define parameters for autoprocessing for chromatograms, choose Display and then Ranges from the drop down menu. When the Ranges dialog box opens, select Autoprocessing and click Use user defined for Mass Tolerance and set it as $6 \mathrm{ppm}$. Mass precision is set at 5 Decimals. For display options, choose Display and then Display Options. Select Labels and choose Retention time (2 Decimals) and Area.

b. Activate the spectrum cell (bottom panel) by selecting the pin 9 at the upper right corner. To define parameters for autoprocessing for spectra, choose Display and then Ranges from the drop down menu. When the Ranges dialog box opens, select Autoprocessing and click Use user defined for Mass Tolerance and set it as $6 \mathrm{ppm}$. Mass precision is set at 5 Decimals. For display options, choose Display and then Display Options. Select Labels and choose Mass (5 Decimals).

c. To save the settings, select File and then Layout from the drop down menu, choose Save as Default. The above settings for autoprocessing and display will be used for subsequent quantification of MS peaks.

2. Use the $\mathrm{m} / \mathrm{z}$ ratios $(+2,+3,+4)$ calculated from MS-Product to search ions containing the corresponding $\mathrm{m} / \mathrm{z}$ values. 
a. Select the chromatogram cell and choose Display then Ranges from the drop down menu.

b. When the Ranges dialog box opens, in the Plot properties, choose Scan filter FTMS + $\mathbf{p}$ NSI Full mass [350.00-1750.00] from the drop down menu.

c. Enter the values for $+2,+3$ and $+4 \mathrm{~m} / \mathrm{z}$ in Ranges.

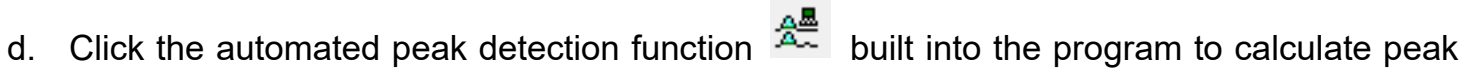
area (Figure 2).

e. Record integrated peak area in the Microsoft Excel spreadsheet once verified (see Step C3).

3. Automated peaks from Qual Browser are verified by the followings.

a. The retention time of Cys-iodoacetanilide or $\mathrm{Cys}^{-13} \mathrm{C}$-iodoacetanilide labeling of the same peptide should be identical since ${ }^{12} \mathrm{C}$-IPA and ${ }^{13} \mathrm{C}$-IPA are identical in their chemical properties, and hence the two species of peptides of the same sequence should resolve on the column in identical fashion (Figure 2).

b. The retention time of a peptide identified by Mascot database search and Qual Browser should be of similar value and should not be differed by more than $0.02-0.03 \mathrm{~min}$.

c. Compare the retention time from Mascot search which is in seconds (rtinseconds) to verify peaks in the Qual Browser.

d. Check the isotopic distribution of the $\mathrm{m} / \mathrm{z}$ ratios ( +2 or +3 or both). For $\mathrm{m} / \mathrm{z}$ ratio of +2 , the isotopic peaks should differ by 0.5 , and for $\mathrm{m} / \mathrm{z}$ ratio of +3 , the isotopic peaks should differ by 0.33 (Figure 2 ).

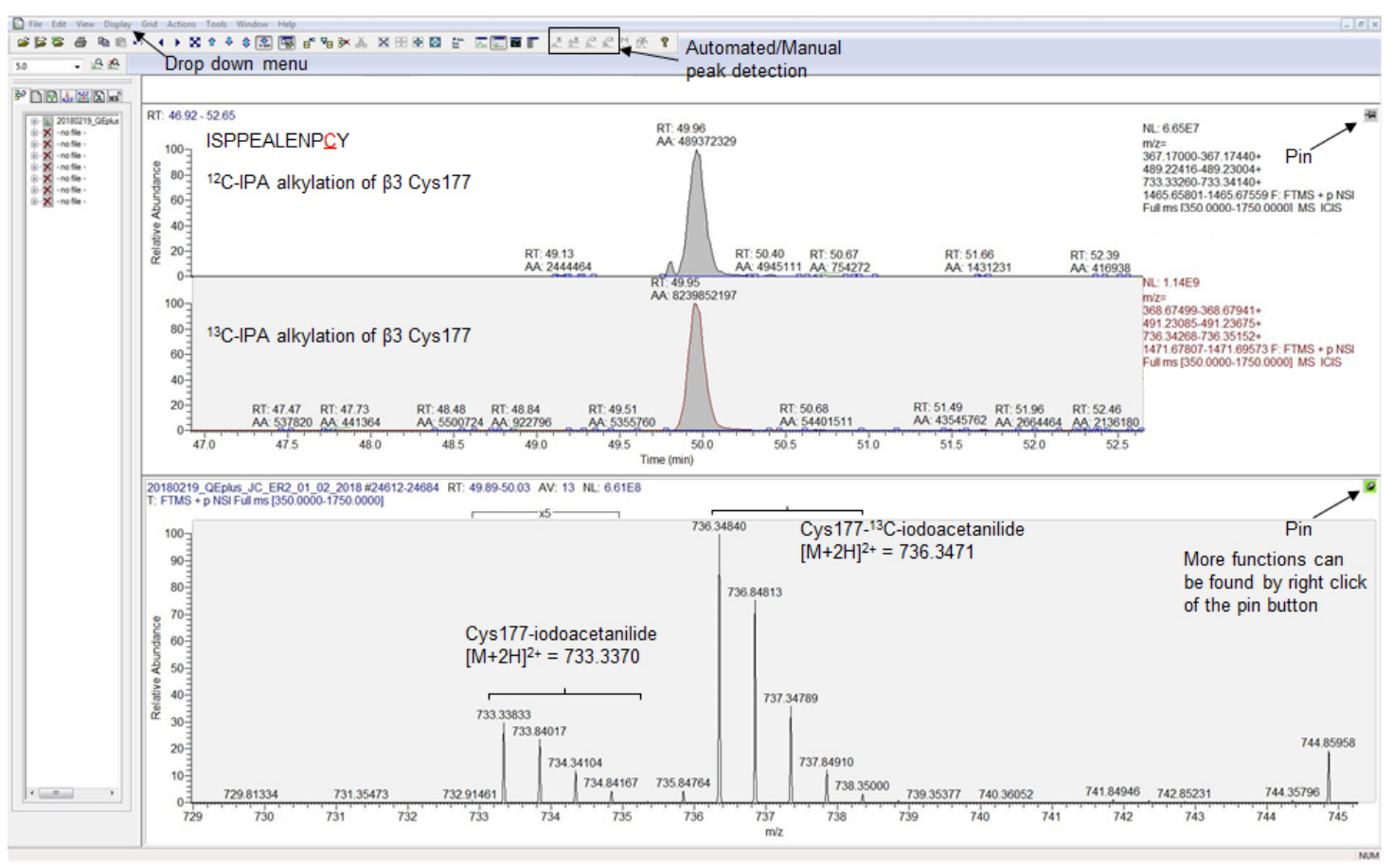

Figure 2. Screenshot of the XCalibur Qual Browser Window showing automated peaks detected for the peptide ISPEALEPCY labeled with ${ }^{12} \mathrm{C}$-IPA or ${ }^{13} \mathrm{C}$-IPA. The two peptide 
species have identical retention times, and the automated area is used for quantification of their abundance. The automated peaks correspond to $\mathrm{m} / \mathrm{z}$ of 733.33833 and 736.34840 for ISPPEALENPC(133.05276)Y and ISPPEALENPC(139.07289)Y respectively, with an isotopic mass distribution of 0.5 confirming their $\mathrm{m} / \mathrm{z}$ ratios as +2 . Utilities such as Drop down menu, pin button, and automated peak detection are shown by black arrows.

4. The fraction of reduced disulfide bond is expressed by the area for Cys-iodoacetanilide labeled

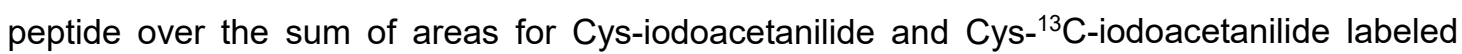
peptides.

$$
\text { Relative abundance of Reduced Cys }=\frac{\text { Area of Cys-iodoacetanilide }}{\text { Sum of areas of Cys-iodoacetanilide and Cys-13C-iodoacetanilide }}
$$

D. Quantification of the abundance of two cysteine-containing peptide using XCalibur Qual Browser

1. For peptides containing two cysteines such as YCNCTTR from $\beta 3$, alkylation with ${ }^{12} \mathrm{C}$-IPA and ${ }^{13} \mathrm{C}$-IPA will give rise to four species of the same peptide; fully reduced, partially reduced and fully oxidized (Table 4).

a. There are two species for the partially reduced peptide since it can be a combination of reduced Cys1 and oxidized Cys2, or vice versa. Both species of partially reduced peptide have identical $\mathrm{m} / \mathrm{z}$ ratios. Hence the area generated by Qual browser for partially reduced peptide is the sum of both species.

b. To delineate their percentage of abundance, $b$ and $y$ ions derived from peptide fragmentation that are unique to Cys 1 and Cys2 are searched from the tandem mass spectrum, and their intensities are used for quantification.

c. The mass for $b$ and $y$ ions of YC(133.05276)NC(139.07289)TTR and YC(133.09.07289)NC(133.05276)TTR can be calculated using protein prospector (Table 5).

d. Tabulate the mass for unique $b$ and $y$ ions using a Microsoft Excel spreadsheet. 
Table 4. Monoisotopic $\mathrm{m} / \mathrm{z}$ ratios for the $\beta 3$ integrin YCNCTTR peptide alkylated with ${ }^{12} \mathrm{C}$ IPA and ${ }^{13} \mathrm{C}$-IPA

\begin{tabular}{|c|c|c|c|c|}
\hline \multirow[t]{2}{*}{ Cys-label } & \multirow[t]{2}{*}{ Sequence* } & \multicolumn{3}{|c|}{$\mathrm{m} / \mathrm{z}$} \\
\hline & & +2 & +3 & +4 \\
\hline $\begin{array}{l}{ }^{12} \mathrm{C}-\mathrm{IPA} \\
\text { Fully reduced }\end{array}$ & $\begin{array}{l}\mathrm{YC}(133.05276) \mathrm{NC}(133.05276) \\
\text { TTR }\end{array}$ & 564.2179 & 376.4810 & 282.6126 \\
\hline $\begin{array}{l}{ }^{12} \mathrm{C}-\text { IPA } \\
{ }^{13} \mathrm{C}-I P A \\
\text { Partially } \\
\text { reduced }\end{array}$ & $\begin{array}{l}\text { YC(133.05276)NC(139.07289) } \\
\text { TTR } \\
\text { YC(139.07289)NC(133.05276) } \\
\text { TTR }\end{array}$ & 567.2279 & 378.4877 & 284.1176 \\
\hline $\begin{array}{l}{ }^{13} \mathrm{C}-\text { IPA } \\
\text { Fully oxidized }\end{array}$ & $\begin{array}{l}\text { YC(139.07289)NC(139.07289) } \\
\text { TTR }\end{array}$ & 570.2380 & 380.4944 & 285.6226 \\
\hline
\end{tabular}

${ }^{*} Y C N C T T R$ is a glycosylated peptide where $\mathrm{N}$ becomes deamidated after PNGase $\mathrm{F}$ treatment, and the actual peptide should be YCN(deamidated)CTTR.

Table 5. Values of $b$ and $y$ ions generated from partially reduced peptide YCNCTTR*

\begin{tabular}{|l|l|l|l|l|l|l|l|l|l|l|l|}
\hline \multicolumn{4}{|l}{ YC(133.05276)NC(139.07289)TTR } & \multicolumn{4}{|l|}{ YC(139.07289)NC(133.05276)TTR } \\
\hline & $b$ & Seq & $y$ & $y^{+2}$ & & & $B$ & Seq & $Y$ & $y^{+2}$ & \\
\hline 1 & & Y & & & 7 & 1 & & Y & & & 7 \\
\hline 2 & 400.1325 & C & 970.3853 & 485.6963 & 6 & 2 & 406.1527 & C & 970.3853 & 485.6963 & 6 \\
\hline 3 & 515.1595 & N† & 734.3233 & 367.6653 & 5 & 3 & 521.1796 & N† & 728.3032 & 364.6552 & 5 \\
\hline 4 & 757.2416 & C & 619.2964 & 310.1518 & 4 & 4 & 757.2416 & C & 613.2763 & 307.1418 & 4 \\
\hline 5 & 858.2892 & T & 377.2143 & 189.1108 & 3 & 5 & 858.2892 & T & 377.2143 & 189.1108 & 3 \\
\hline 6 & 959.3369 & T & 276.1666 & 138.587 & 2 & 6 & 959.3369 & T & 276.1666 & 138.587 & 2 \\
\hline 7 & 400.1325 & R & 175.119 & 88.0631 & 1 & 7 & 400.1325 & R & 175.119 & 88.0631 & 1 \\
\hline
\end{tabular}

*Unique $b$ and $y$ ions are highlighted in grey. Values for $b$ and $y$ ions are obtained from MS Product tool in Protein Prospector.

$\dagger N$ is a glycosylation site and becomes deamidated post PNGase $F$ treatment.

2. The MS/MS spectrum for the partially reduced YCNCTTR peptide is then used for quantification.

a. To bring up the tandem mass spectrum for the partially reduced YCNCTTR peptide, select chromatogram cell to make it active and bring up the Ranges dialog box.

b. In the Plot properties, choose TIC as plot type and in the scan filter drop down menu, select FTMS + c NSI d Full ms2 567.22 , which is the $\mathrm{m} / \mathrm{z}$ ratio of +2 . Some peptides may require $\mathrm{m} / \mathrm{z}$ ratio of +3 to search for the tandem spectrum. If the exact $\mathrm{m} / \mathrm{z}$ ratio is not available from the menu, select one that is within the range of \pm 0.5 .

c. On the chromatogram cell, select the ion peak that is within $1 \mathrm{~min}$ of the retention time of the automated peak area generated from the full scan (Figure 3). 
d. Select spectrum cell to make it active and the tandem mass spectrum corresponding to the ion peak selected on the chromatogram cell will be displayed. If the scan \# of the tandem spectrum is known (from Mascot search), apply Default Layout and search for ion peak with the scan \# from the chromatogram cell to display the tandem spectrum in the spectrum cell.

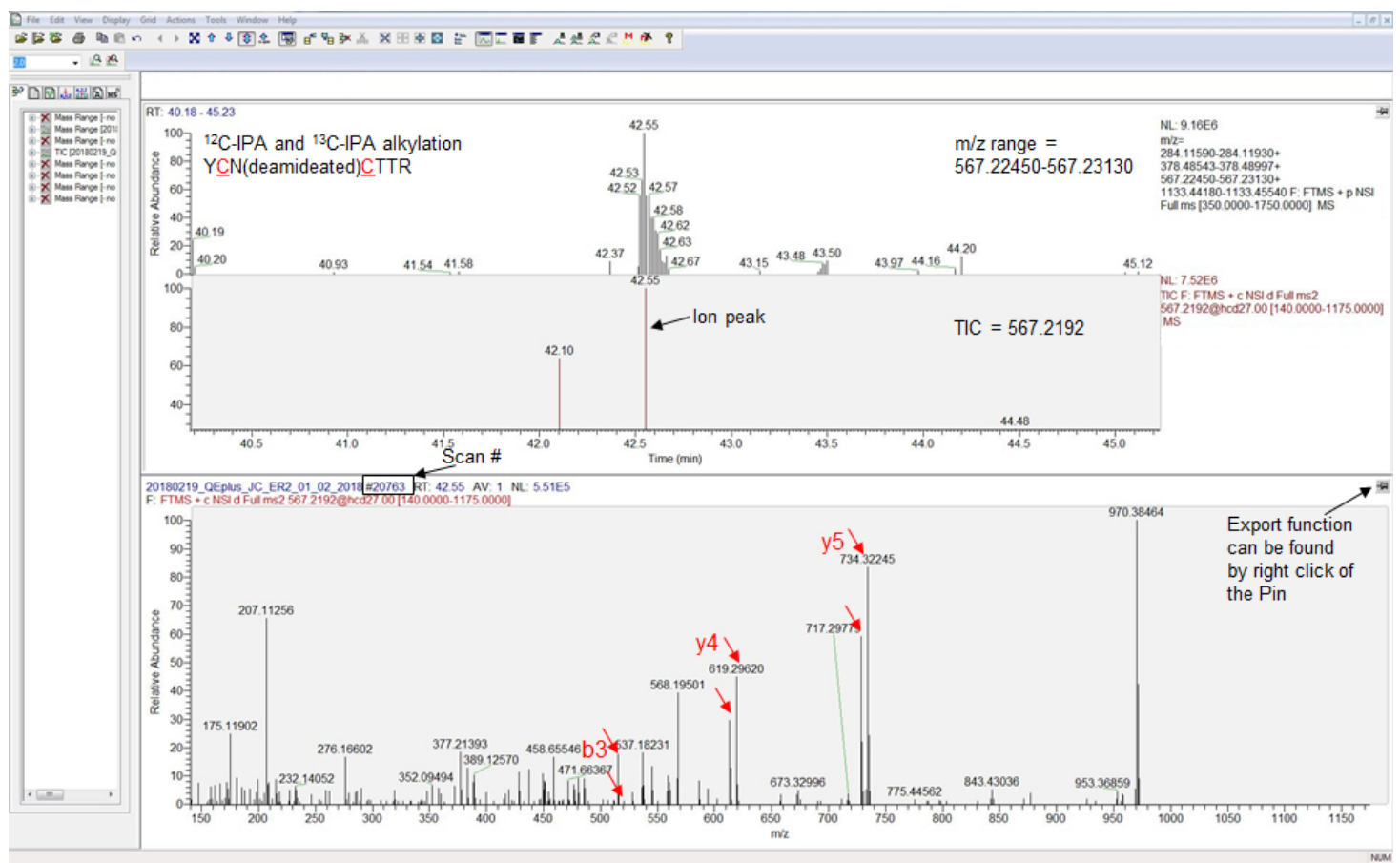

Figure 3. Screenshot of the XCalibur Qual Browser Window for quantification of YCNCTTR peptide labeled with Cys-iodoacetanilide and $\mathrm{Cys}-{ }^{13} \mathrm{C}$-iodoacetanilide. Automated peak detected for $\mathrm{m} / \mathrm{z}=567.2279$ (mass range 567.22450-567.23130), ion peak (TIC) with $\mathrm{m} / \mathrm{z}=567.2192$ and the corresponding tandem mass spectrum (scan \# 20763) are shown. Unique $b$ and $y$ ions for Cys 1 and Cys2 are found in the spectrum (red labels and arrows). The intensities of the fragment ions can be exported for quantification.

3. To view and export the intensity values of all ion masses.

a. Select View from the drop down menu, then choose Spectrum list. The ions masses and their exact and relative intensities will be shown.

b. To export the intensity data, right click the mouse on the pin button, select Export then Clipboard (Exact mass).

c. Paste data to a spreadsheet in Microsoft Excel.

4. To calculate percentage of each species of the partially reduced peptide:

a. Using the filter function in Microsoft Excel, search for masses of all unique $b$ and $y$ ions (values rounded to whole digit) and record their intensities. 
b. The relative abundance of the two partially reduced peptide species is expressed as:

\author{
Sum of intensities of unique ion masses \\ Relative abundance $=\frac{\text { for one peptide species }}{\text { Sum of intensities of all unique ion masses }} \times$ peak area of the partially reduced peptide \\ for both peptide species
}

5. The total abundance of the reduced form for each cysteine of the peptide is the sum of the areas for fully reduced cysteine and that of partially reduced form of cysteine. Its relative abundance is expressed as a percentage of the Cys-iodoacetanilide to the sum of Cys-iodoacetanilide and Cys- ${ }^{13} \mathrm{C}$-lodoacetanilide.

6. Cysteine containing peptides identified by differential cysteine alkylation and mass spectrometry can be found in (Passam et al., 2018, supplementary file 1). A total of 68 cysteine-containing peptides were identified by this methodology with 35 cysteines representing 24 of the 28 disulfide bonds in $\beta 3$ integrin (Passam et al., 2018) which is $87 \%$ coverage of $\beta 3$ disulfide bonds. Note: Unmapped cysteines are found in peptides containing 3-5 cysteines and are beyond the limit of the current approach. Other proteomic approaches are necessary to overcome this limitation.

\title{
$\underline{\text { Notes }}$
}

1. Redox state of disulfides in allb $\beta 3$ will slightly vary between batches of purified allb $\beta 3$, but differences are generally non-significant.

2. To measure the redox state of disulfide bonds in $\beta 3$ integrin on platelet surface, free cysteines on the surface of wash platelets are labeled with $5 \mathrm{mM}{ }^{12} \mathrm{C}$-IPA in PBS for $30 \mathrm{~min}$ in the dark. $\beta 3$ integrin is then subjected to immunoprecipitation as described in Passam et al. 2018. Eluates were analyzed by SDS-PAGE, followed by excision of gel band, DTT reduction, and ${ }^{13} \mathrm{C}$-IPA labeling as described in this protocol. ${ }^{12} \mathrm{C}$-IPA is also cell-permeable and therefore can be used to label free cysteine thiols in proteins that reside in a cell. Cells are lysed in buffered containing $5 \mathrm{mM}{ }^{12} \mathrm{C}-\mathrm{IPA}$, and the protein of interested is purified by immunoprecipitation.

\section{$\underline{\text { Recipes }}$}

1. PBS

$8 \mathrm{~g} \mathrm{NaCl}$

$0.2 \mathrm{~g} \mathrm{KCl}$

$1.44 \mathrm{~g} \mathrm{Na}_{2} \mathrm{HPO}_{4}$

$0.24 \mathrm{~g}$ of $\mathrm{KH}_{2} \mathrm{PO}_{4}$

Adjust the $\mathrm{pH}$ to 7.4 with $\mathrm{HCl}$

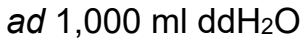


2. Gel destaining solution

$100 \mathrm{ml}$ methanol (10\%)

$50 \mathrm{ml}$ acetic acid $(5 \%)$

ad $1,000 \mathrm{ml} \mathrm{ddH} \mathrm{H}_{2} \mathrm{O}$

3. $50 \mathrm{mM}{ }^{12} \mathrm{C}-I P A / D M S O$ solution (freshly prepared)

$13.055 \mathrm{mg}{ }^{12} \mathrm{C}$-IPA

ad $1 \mathrm{ml}$ DMSO

4. $50 \mathrm{mM}{ }^{13} \mathrm{C}-\mathrm{IPA} / \mathrm{DMSO}$ solution (freshly prepared)

$13.055 \mathrm{mg}{ }^{13} \mathrm{C}$-IPA

ad $1 \mathrm{ml}$ DMSO

5. $5 \mathrm{mM}{ }^{13} \mathrm{C}$-IPA/25 mM ammonium bicarbonate

$1 \mathrm{ml} 50 \mathrm{mM}{ }^{13} \mathrm{C}$-IPA/DMSO solution

ad $10 \mathrm{ml} 25 \mathrm{mM}$ ammonium bicarbonate buffer

6. $25 \mathrm{mM}$ ammonium bicarbonate buffer

$1.9764 \mathrm{~g}$ ammonium bicarbonate

ad $1,000 \mathrm{ml} \mathrm{ddH}_{2} \mathrm{O}$

7. $25 \mathrm{mM}$ ammonium bicarbondate $/ 50 \%$ acetonitrile buffer

$1.9764 \mathrm{~g}$ ammonium bicarbonate

$500 \mathrm{ml}$ acetonitrile

ad $1,000 \mathrm{ml} \mathrm{ddH_{2 } \mathrm { O }}$

8. $25 \mathrm{mM}$ ammonium bicarbonate/10 $\mathrm{mM}$ calcium chloride buffer (freshly prepared)

$990 \mu \mathrm{l} 25 \mathrm{mM}$ ammonium bicarbonate buffer

$10 \mu \mathrm{l} 1 \mathrm{M}$ calcium chloride solution

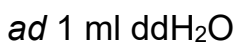

9. $1 \mathrm{M}$ calcium chloride solution

$5.549 \mathrm{~g}$ calcium chloride

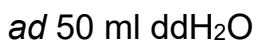

10. $40 \mathrm{mM} \mathrm{DTT} / 25 \mathrm{mM}$ ammonium bicarbonate (freshly prepared)

$61.7 \mathrm{mg}$ DTT

ad $10 \mathrm{ml} \mathrm{ddH} \mathrm{H}_{2} \mathrm{O}$

11. $1 \mathrm{mM} \mathrm{HCl}$ solution

$100 \mu \mathrm{l} 1 \mathrm{M} \mathrm{HCl}$

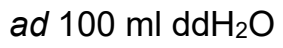

12. $50 \mathrm{mM}$ acetic acid

$285.7 \mu \mathrm{l}$ glacial acetic acid (99.9\%)

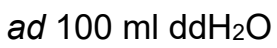

13. $5 \%$ formic acid

$5 \mathrm{ml}$ formic acid

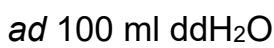


14. $5 \%$ formic acid $/ 50 \%$ acetonitrile buffer

$5 \mathrm{ml}$ formic acid (>95\%)

$50 \mathrm{ml}$ acetonitrile

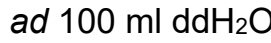

15. $1 \%$ trifluoroacetic acid solution

$1 \mathrm{ml}$ trifluoroacetic acid $(99.9 \%)$

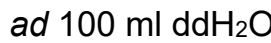

16. Wetting solution ( $0.1 \%$ trifluoroacetic acid $/ 50 \%$ acetonitrile)

$10 \mathrm{ml} 1 \%$ trifluoroacetic acid

$50 \mathrm{ml}$ acetonitrile

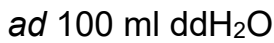

17. Equilibration solution ( $0.1 \%$ trifluoroacetic acid $/ 5 \%$ acetonitrile)

$10 \mathrm{ml} 1 \%$ trifluoroacetic acid

$5 \mathrm{ml}$ acetonitrile

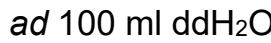

18. $0.1 \%$ formic acid

$100 \mu \mathrm{l}$ formic acid (> 95\%)

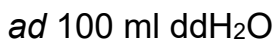

19. HPLC Buffer $A$

95\% LC-grade water

$5 \%$ acetonitrile

$0.1 \%$ formic acid

ad $1,000 \mathrm{ml} \mathrm{dd} \mathrm{H}_{2} \mathrm{O}$

20. HPLC Buffer B

$20 \%$ LC-grade water

$80 \%$ acetonitrile

$0.1 \%$ formic acid

ad $1,000 \mathrm{ml} \mathrm{ddH} \mathrm{H}_{2} \mathrm{O}$

\section{Acknowledgments}

This work was supported by the Helen and Robert Ellis Fellowship and Tony Basten Postdoctoral Fellowship from the Sydney Medical School Foundation. This work is adapted from previous work (Passam et al., 2018).

\section{Competing interests}

The author declares no conflict of interest. 


\section{References}

1. Chambers, J. E., Tavender, T. J., Oka, O. B. V. Warwood, S., Knight, D. and Bulleid, N. J. (2010). The reduction potential of the active site disulfides of human protein disulfide isomerase limits oxidation of the enzyme by Ero1a. J Biol Chem. 285 (38): 29200-29207.

2. He, L., Diedrich, J., Chu, Y. Y. and Yates, J. R., 3rd (2015). Extracting accurate precursor information for tandem mass spectra by rawconverter. Anal Chem 87(22): 11361-11367.

3. Manickam, N., Sun, X., Hakala, K. W., Weintraub, S. T. and Essex, D. W. (2008). Thiols in the allbB3 integrin are necessary for platelet aggregation. Br J Haematol 142(3): 457-465.

4. Pasquarello, C., Sanchez, J. C., Hochstrasser, D. F. and Corthals, G. L. (2004). N-tbutyliodoacetamide and iodoacetanilide: two new cysteine alkylating reagents for relative quantitation of proteins. Rapid Commun Mass Spectrom 18(1): 117-127.

5. Passam, F., Chiu, J., Ju, L., Pijning, A., Jahan, Z., Mor-Cohen, R., Yeheskel, A., Kolsek, K., Tharichen, L., Aponte-Santamaria, C., Grater, F. and Hogg, P. J. (2018). Mechano-redox control of integrin de-adhesion. Elife 7: e34843. 